Archives of Agriculture and Environmental Science

\title{
Analysis of agricultural growth and its determinant factors in Nepal
}

\author{
Amrit Dumre ${ }^{1^{*}}$ (D) , Shiva Chandra Dhakal ${ }^{2}$, Mohan Acharya ${ }^{1}$ and Prabin Poudel ${ }^{1}$ \\ ${ }^{1}$ M.Sc. Agricultural Economics, Agriculture and Forestry University, Rampur, Chitwan, NEPAL \\ ${ }^{2}$ Department of Agricultural Economics and Agribusiness Management, Agriculture and Forestry University, Rampur, Chitwan, \\ NEPAL \\ "Corresponding author's E-mail: amrit8afu@gmail.com
}

\section{ARTICLE HISTORY}

Received: 17 December 2020

Revised received: 26 February 2020

Accepted: 13 March 2020

\section{Keywords}

Agricultural credit

Agricultural transformation

Agri-GDP

Economic growth

\section{ABSTRACT}

This paper critically analyzes the trajectory of agricultural growth and its determinants in Nepal. Agricultural growth is vital for stimulating overall economic growth. The World Bank research shows strong statistical link between agricultural and overall economic growth in less developed countries. Economic growth and agricultural growth in Nepal also show strong correlation $\left(r=0.7501^{* * *}\right.$ ). Agricultural transformation is characterized by declining share of agriculture in national employment and GDP, and increasing share of secondary sectors like industry, service and manufacturing. However, this structural shift seems unplanned and ungoverned in case of Nepal. The contribution of agriculture to GDP is continuously declining, but, the growth of secondary sectors likes industry and manufacturing still looks stagnant. At this incipient stage of agricultural transformation, productivity growth in agriculture is both a necessary as well as sufficient condition for the development of economy as a whole. Agricultural growth depends on institutional (agricultural credit and land holdings), infrastructural (irrigated area, farm mechanization, electricity, storage, transportation, agricultural market), technological (high yielding varieties or improved seed, fertilizers and pesticides) and socioeconomic factors (population, poverty and literacy). Policies strengthening these determinants can help Nepal in achieving targeted sustained economic growth.

(C)2020 Agriculture and Environmental Science Academy

Citation of this article: Dumre, A., Dhakal, S.C., Acharya, M. and Poudel, P. (2020). Analysis of agricultural growth and its determinant factors in Nepal. Archives of Agriculture and Environmental Science, 5(1): 55-60, https://dx.doi.org/10.26832/24566632.2020.050108

\section{INTRODUCTION}

Nepal is one of the least developed and low income countries in the world. Nepal aims to graduate from least developed country to developing country by the year 2022 and low income to middle income country by 2030 (MoF, 2018). Out of the three criteria (i.e. Human Asset Index, Economic Vulnerability Index and Per Capita Income) set by UN to graduate to the league of developing nations, two of them have been met but Nepal lies far behind in the Per Capita Income (Shrestha, 2018). Low per capita income is attributed by the high agriculture dependent rural population.

Agriculture is one of the powerhouses of Nepalese economy contributing 26.5 percent of total national gross domestic product (GDP) (MoF, 2018). It is both the source of food as well as the economic wealth of the nation. Majority of the population (65.6 percent) are involved in agriculture sector (MoAD, 2018). Major portion of total export depends on agriculture; large cardamom, ginger, lentil, tea, coffee being the major exportable commodities. The fate of development of Nepal is highly dependent upon the growth of Agri-GDP as the large proportion of population as well as industries and trade are agriculture dependent. Growth in agriculture sector is thus, the panacea for achieving economic development in Nepal which in turn depends on the several factors. Researchers have emphasized labor force growth, human capital, financing, capital accumulation in public infrastructures and research and technology as major determinants in examining agricultural growth (Thapa, 2011). This paper makes an attempt to critically analyze the sectoral structure of GDP, find the relation between economic 
growth and agricultural growth and determine the factors affecting agricultural growth and thus find out where in Nepal lies in the path of agricultural transformation.

\section{METHODOLOGY}

This study is basically carried out using publicly available data sources, such as Economic Survey Reports (FY 2003/04, 2012/13 and 2018/19) and World Bank database. Relevant journal articles, reports and books were consulted for having detail insight on determinants of agricultural growth. Descriptive statistical tools such as pie-chart, bar-diagram was used to represent sectoral contribution to GDP, comparative study of productivity of major crop in South Asia. Trend line was used to study the trajectory of agricultural growth, pattern of contribution of agricultural and non-agricultural sector to GDP and growth of agricultural credit flow. Correlation analysis was employed to find out the relation between agricultural growth and economic growth in Nepal. MS-Excel and STATA (version 12) was used for this purpose.

\section{RESULTS AND DISCUSSION}

\section{Sectoral contribution to GDP}

The contribution of agriculture sector to GDP is gradually decreasing annually while that of non agricultural sector is increasing. In the FY 2017-18 the contribution of agriculture and non agricultural sector to GDP was 28.1 percent and 71.9 percent respectively (Figure 1). The contribution of agriculture to GDP was projected to decline to 27 percent in the FY 2018-19 (MoF, 2018). Nepal has shown a drastic change in the structure of employment and GDP composition in last few years. According to World Bank, the share of agriculture in GDP has decreased drastically from around 69 percent (1966) to 26 percent (2016) whereas the contribution of service and industry to GDP shows the increasing trend which is believed as good indicator of an economy (World Bank, 2019).

Nepal's economy is enjoying a solid expansion through the reconstruction activities after the devastating earthquake of 2015. The economic growth in the recent two-three years shows sustained growth around 6 percent. The preliminary draft of concept paper of $15^{\text {th }}$ five year plan has set a target to achieve a minimum economic growth of 9.4 percent per annum next five year Similarly, contribution of agriculture sector and industrial sector in national GDP is projected to reach 22.1 percent and 20.3 percent respectively (Himalayan Times, 2019). As an economy develops, the relative contribution of agriculture to output and employment must decline (Joshi, 2018). A declining share for agriculture in national employment and GDP is an inevitable consequence of economic progress (Cervantesgodoy and Dewbre, 2010). This is largely due to higher income elasticity of demand for non-agricultural goods and services. This process of agricultural transformation is usually accompanied by rising incomes and lower incidence of poverty of the agriculture dependent population. Per Capita Income (PCI) of

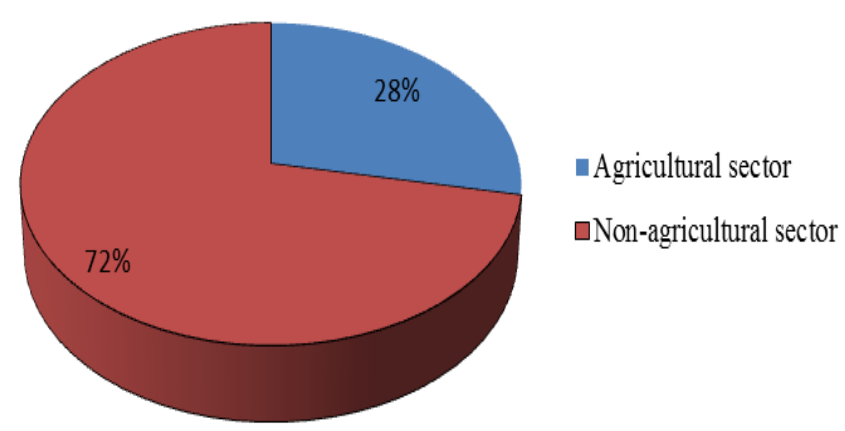

Figure 1. Sectoral contribution to GDP in FY 2017-18.

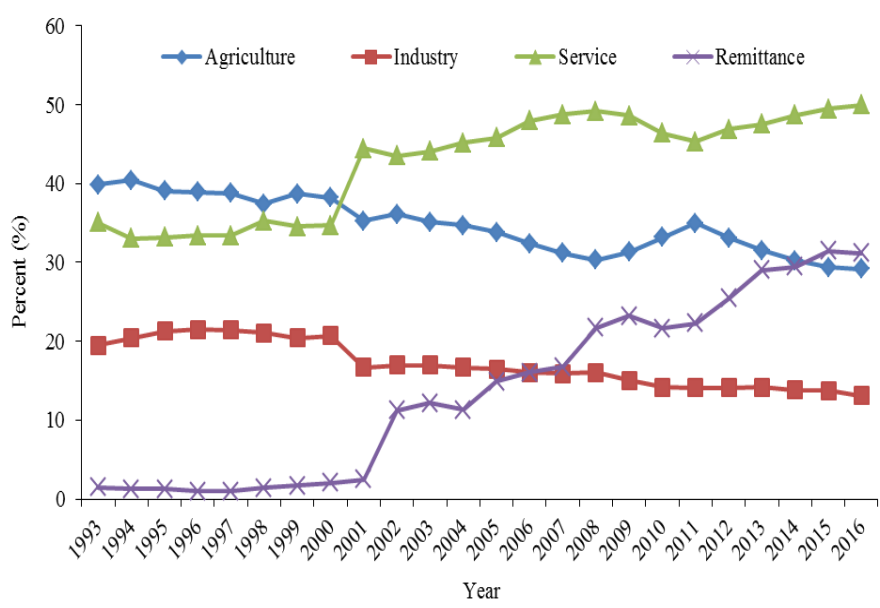

Figure 2. Pattern of sectoral contribution to GDP.

Nepal has crossed 1,000 US dollar and poverty rate has sharply declined which is marked as a major boost to graduate from least developed to developing country.

The experiences of developed countries show the transfer of labor force from less productive agricultural sector to more productive non-agricultural sector. However, story of agricultural transformation is rather different in Nepal. The contribution of agriculture to GDP is continuously declining, but, the growth of secondary sectors like industry manufacturing etc. still seems stagnant. The service sector, on the other hand, is growing at faster rate. Agricultural labor force is in continuous decline due to heavy outmigration. The economy has become remittance dependent and agriculture still remains the less productive sector. Therefore, the structural shift in agriculture is found to be unsystematic. Without the sustainable development in other sectors like service and industry, such shift could be suicidal for a country like Nepal having deep rooted life style, culture, religion and knowledge based agriculture (Satyal, 2010). Under these circumstances, higher agricultural growth is vital for the sustainable economic development (Figure 2).

\section{Economic growth and agricultural growth}

The World Bank research shows strong statistical link between agricultural and overall economic growth in less developed countries. Countries with agricultural share of GDP greater than 20 percent in 1970s exceeded 3 percent a year in 17 of the 23 countries whose GDP growth rate was above 5 percent a year while 11 of the 17 countries with GDP growth below 3 percent a 
year managed agricultural growth of only 1 percent or less (Timmer, 1988). Analyzing the relation between annual agricultural growth rate and GDP growth rate in Nepal shows a significant positive correlation $\left(r=0.7501^{* * *}\right)$ at 1 per cent level of significance. This indicates agriculture is a key sector for economic growth in Nepal.

The trend line in Figure 3 shows agricultural growth is increasing but the rate is not significant. In the fiscal year 2017/18, GDP at basic price increased by 6.3 percent which is expected to increase by 6.8 percent in the fiscal year 2018/19. Favorable weather conditions, increased access of irrigation facilities and easy availability of seeds and chemical fertilizer contributed to increase the production and productivity of agricultural sector in the same year. Gross Value Added (GVA) of agriculture and non-agricultural sector is estimated to grow by 5 percent and 7.5 percent respectively. Data of last decade shows the average annual economic growth rate of 4.6 percent with 3.1 percent and 5.3 percent average annual growth rate respectively in agricultural and non-agricultural sector (Figure 4). Nepalese economy was devastated by the earthquake and border blockade in the fiscal year 2015/16. Reformative works from that stage has made it possible to expand the economy with an

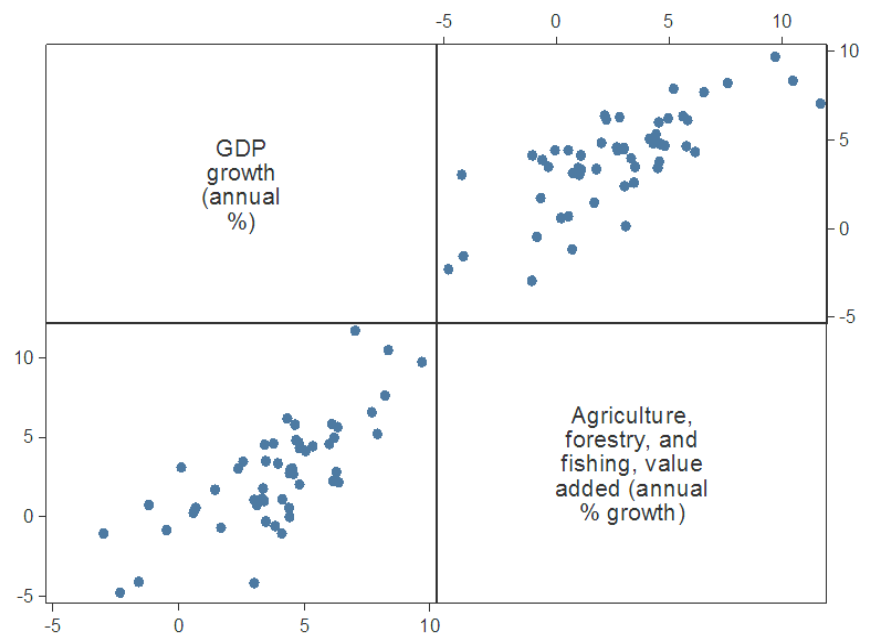

Figure 3. Scatterplot matrix for correlation analysis of agricultural growth and economic growth. annual average of 7.3 percent from the fiscal year 2017/18 (MoF, 2018).

\section{Determinants of agricultural growth}

Cereal crops, horticulture, livestock, fisheries and forestry are the major subsectors of agricultural sector of Nepal. Cereal crops contribute the highest (49.4 per cent) to the agri-GDP followed by livestock (25.8 per cent), horticulture (16.7 per cent) and forestry (8.1 percent) (Joshi, 2018). Growth of agriculture sector requires the increased productivity in all these subsectors. The productivity growth in agriculture is both a necessary and sufficient condition for the development of this sector as well as the economy. However, productivity of major subsector of Nepalese agriculture seems stagnant. Productivity of maize, in Nepal, is at the bottom in South Asia while that of rice is only higher than Afghanistan (Figure 5). Contraction of agricultural land due to escalating urbanization and plotting in one hand and declining of agricultural labor force on the other hand has exacerbated the situation of poor agricultural productivity in Nepal. We are facing a challenge to increase productivity from declining agricultural land and agricultural labor force. This requires a capital intensive technology driven agricultural sector.

Agricultural growth depends on institutional (agricultural credit and land holdings), infrastructural (irrigated area, farm mechanization, electricity, storage, transportation, agricultural market), technological (high yielding varieties or improved seed, fertilizers and pesticides) and socioeconomic factors (population, poverty and literacy). Thapa (2011) identified population growth rates, male literacy, improved seeds and chemical pesticides as important contributors in agricultural growth of Nepal. The contribution of female literacy, road density, irrigation coverage, agricultural credit and mineral fertilizer were also significant contributors to agricultural growth in Nepal. Awan and Mustafa (2013) found total cropped area, irrigation water; improved seed distribution and import of pesticide have significant impact on growth of agri-GDP. Major determinants of agricultural growth in Nepal are:

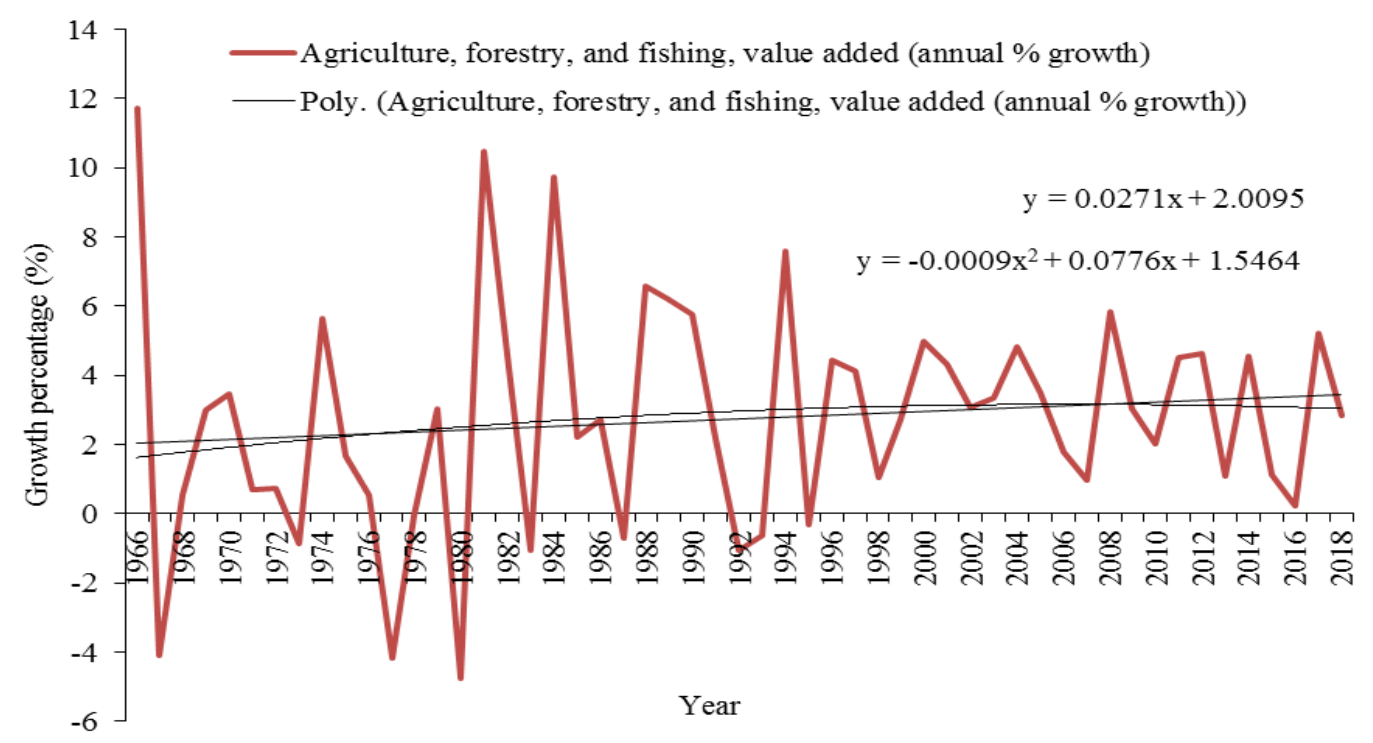

Figure 4. Trend of agricultural growth in Nepal from the year. 


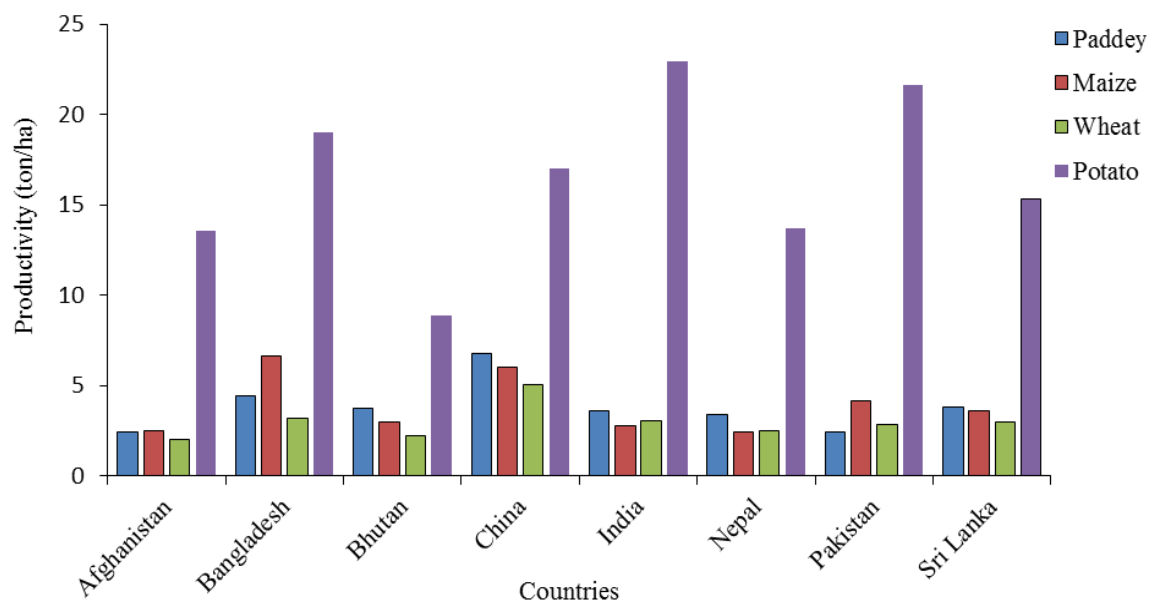

Figure 5. Comparative study of productivity of major crops in different countries (Source: Joshi, 2018).

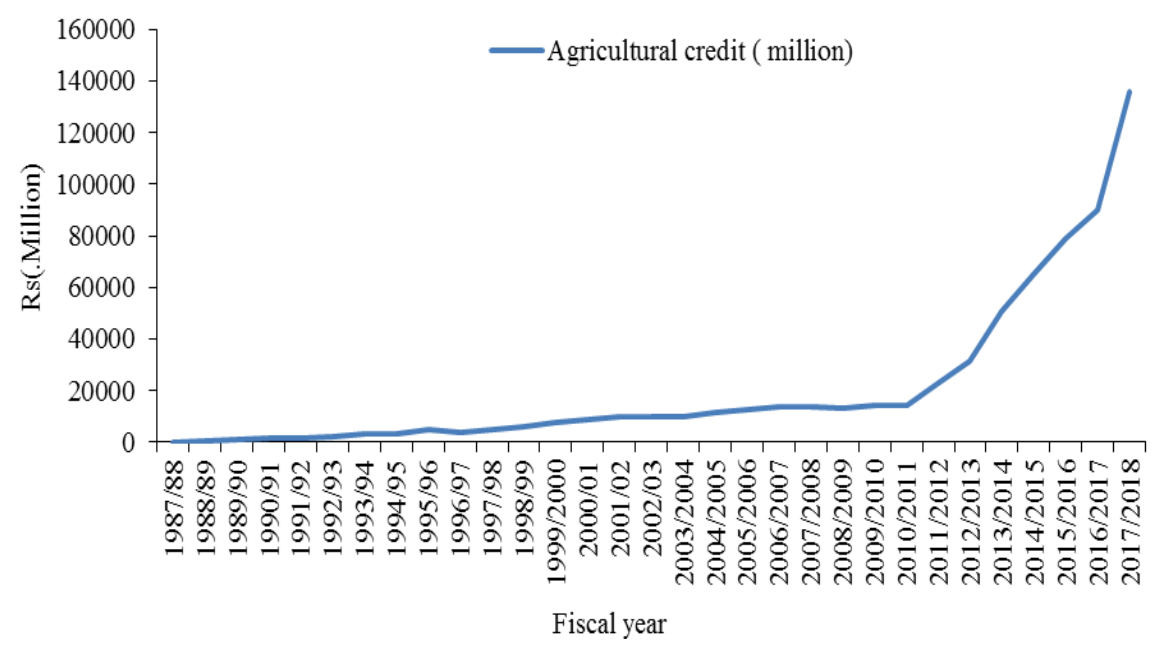

Figure 6. Status of agricultural credit in Nepal (Source: MoF, 2004), (MoF, 2013) and (MoF, 2018).

\section{Agricultural credit}

Least developed countries like Nepal needs improved technology for increasing agricultural productivity and sustained agricultural growth. These modern agricultural technologies (chemical fertilizer, improved seed, irrigation, farm machineries etc.) are capital intensive. Adoption of these technologies demands increased credit facilities to the resource poor farmers. Access to credit can promote the adoption of high yielding technologies in agriculture (Saboor et al., 2009). Easy and cheap credit is the quickest way for increasing the agricultural production (Abedullahet al., 2009). Total amount of Rs. 128.33 billion agricultural credit was mobilized up to mid-march of 2017/18 which increased by 40.6 per cent to Rs. 180.2 billion. This figure was only Rs. 50.91 billion. Since then, there had been about 167 per cent in last five years period and stood as Rs. 135.76 billion in the fiscal year 2017/18 (MoF, 2018). Disbursement of agricultural credit by commercial bank has increased drastically than earlier indicating good sign for agricultural growth (Figure 6).

\section{Agricultural land}

Increase in agricultural land has a positive relation with agricultural productivity. As the cultivated land increases, production also increases, then, it could be expected that agriculture sector contribute larger percentage of its output growth. Odhiambo and Nyangito (2004) and Teshome and Lupi (2018) found positive impact of agricultural land on agricultural growth respectively in Kenya and Ethiopia. Nepal has cultivated land of $30,91,000$ ha and still $10,30,000$ ha arable agricultural land is uncultivated (MoAD, 2018). Escalating urbanization has posed a huge threat on agricultural productivity in Nepal.

\section{Agri-inputs}

The growth of agricultural sector is largely dependent on the availability and use of the agri-inputs like chemical fertilizers, improved seeds, and chemical pesticides. Research shows that at least 30 to 50 per cent yield is attributable to commercial fertilizer nutrient input (Stewart et al., 2005). Use of high yielding varieties seed increases the yield by 45 per cent. Crop losses due to various pests is about 35 per cent (Kafle et al., 2014). Availability of safe and efficacious pesticides and their judicious use is critical for the sustainable increase in agricultural production. Nepal is far behind in using fertilizer per hectare of arable land. Potential demand for fertilizer in Nepal is about 7,00,000 MT of which actual supply was only 3,24,977 MT in the year 2016/17 (Panta, 2018). The average increase of fertilizer use per hectare in Nepal is $3.4 \mathrm{~kg}$ per annum. The sale of improved seed increased from 6911.604 MT in 2016/17 to 8143.958 MT in 2017/18 (MoAD, 2018). Subsidy program on chemical fertilizer and improved seed had impressive effect on their adoption (Bista et al., 2016). 


\section{Rural infrastructure}

Rural infrastructure like road connectivity, transport facilities are the most crucial factors for sustained agricultural growth. Road networks and transport facilities helps in reduction of transportation cost and makes the agricultural products competitive in the market. It gives an encouragement to the farmers and thus helps in increasing agricultural productivity. There has been substantial increase in road network. All district headquarters have been linked to road networks except Humla (MoF, 2018). Linking all the agricultural areas of Nepal with road networks can boost up agricultural production creating favorable environment for rural farmers. Irrigation also plays crucial role in agricultural growth. Bhattarai and Narayanamoorthy (1994) found a strong inverse relationship between incidence of rural poverty and percentage of gross area irrigated in India. Therefore, it is thought as a critical factor for overall development of agricultural sector. Only 1.473 million hectare out of a total of 2.641 million hectares of agricultural land in Nepal had irrigation facility in the fiscal year 2017-18. However, due to lack of availability of sufficient amount of water in the source and delayed implementation of the projects of water transfer, only, 33 per cent areas of irrigated land has irrigation facility throughout 12 months of a year (MoF, 2018). Expansion of additional irrigated area and introduction of modern irrigation technology, in coming days, can enhance the agricultural productivity of Nepal.

\section{Literacy rate}

Adoption of high yielding modern technology is crucial for the increased productivity. Educated people readily adopt these technologies than the illiterate and uneducated one. Literature shows that education has high rates of return to investment, and higher contribution to economic growth rates by improving total factor productivity (Thapa, 2011). Education increases the decision making capacity of the farmers. Nepal has made a substantial improvement in social sector like education. Adult literacy rate increased from 20.57 percent in 1980 to 67.9 per cent in 2018 (World Bank, 2019). This improvement in literacy rate has played important role in human capital development and growth of agricultural productivity in Nepal.

\section{Conclusion}

It is evident from the research that agricultural growth is vital for the overall economic growth for the least developed countries like Nepal (as shown by the strong correlation between agricultural growth and economic growth in Nepal). The process of agricultural transformation is still at the incipient stage in Nepal. The contribution of agricultural sector to GDP is declining but the sectoral contribution of industry and service to GDP still looks stagnant. At this critical stage of agricultural transformation, agriculture driven growth is the current need for the overall economic growth of the nation. Agricultural growth depends on institutional (agricultural credit and land holdings), infrastructural (irrigated area, farm mechanization, electricity, storage, transportation, agricultural market), technological (high yielding varieties or improved seed, fertilizers and pesticides) and socioeconomic factors (population, poverty and literacy). Strengthening of all of these factors is crucial in achieving the targeted double figured economic growth. Declining of agricultural labor force and agricultural land demands the capital intensive technology driven agricultural sector. For this easy and cheap (low interest rate) agricultural credit should be encouraged with regular monitoring. Timely supply of the agricultural inputs as per the farmers' demand should be ensured by the government. Both underground and above ground irrigation facility should be increased. Expansion of the road networks by government is a must to connect rural farmers with market. Policy discouraging conversion of agricultural land into other purpose should be formulated and implemented. Efficient extension services should be provided to increase adoption of high yielding agricultural technologies. It is, thus, imperative for the government to address all these sectors for agricultural as well as economic growth.

\section{ACKNOWLEDGEMENTS}

We would like to acknowledge Dr. Ujjal Tiwari, Assistant Professor, Department of Agricultural Economics and Agribusiness Management for constructive suggestions and guidance. We are indebted by the overwhelming support from our colleagues Seema Karki and Sushma Banjara during the preparation of this article.

Open Access: This is an open access article distributed under the terms of the Creative Commons Attribution 4.0 License, which permits unrestricted use, distribution, and reproduction in any medium, provided the original author(s) if the sources are credited.

\section{REFERENCES}

Abedullah, Mahmood, N., Khalid, M. and Kouser, S. (2009). The role of agricultural credit in the growth of livestock sector: A case study of Faisalabad. Pakistan Veterinary Journal, 29(2): 81-84.

Awan, F. and Mustafa, U. (2013). Key factors contributing to agricultural growth in Pakistan: An application of time series analysis. Journal of Agricultural Economics and Development,1(12): 6-13.

Bhattarai, M. and Narayanamoorthy, A. (1994). Impact of irrigation on agricultural growth and poverty alleviation: Macro level analyses in India. Water Policy Research.

Bista, D. R., Dhungel, S. and Adhikari, S. (2016). Status of fertilizer and seed subsidy in Nepal: review and recommendation. The Journal of Agriculture and Environment, 17: 1-10, https://doi.org/10.3126/aej.v17i0.19854

Cervantes-godoy, D. and Dewbre, J. (2010). Economic Importance of Agriculture for Poverty Reduction (No. 23). OECD, France. https://doi.org/10.1787/5kmmv9s20944-en

Himalayan Times. (2019, March 3). 15th five-year plan targets minimum 9.4pc annual growth. Retrieved from https://thehimalayantimes.com/ business/15th-five-year-plan-targets-minimum-9-4pc-annual-growth/

Joshi, G.R. (2018). Agricultural Economy of Nepal: Development Challenges and Opportunities (First). Sustainable Research \& Development Centre.

Kafle, L., G.C, Y.D., Yang, J., Bhattarai, S., Tiwari, S., Lekhnath Kafle, Yubak Dhoj, G.C, Jeng-Tze Yang, Shankar Bhattarai, S.T. and Katuwal, M. (2014). Integrated Pest Management in Nepal Integrated Pest Management in Nepal, https://doi.org/10.13140/2.1.2563.2324 
MoAD. (2018). Krishi Diary. GoN, MoAD, Agriculture Information and Communication Centre, Hariharbhawan, Lalitpur.

MoF. (2004). Economic survey, 2003/04. Ministry of Finance. Singh Durbar, Kathmandu.

MoF. (2013). Economic Survey , 2012/13. Ministry of Finance. Singh Durbar, Kathmandu.

MoF. (2018). Economic Survey 2017 / 18 Ministry of Finance. Singh Durbar, Kathmandu.

Odhiambo, W. and Nyangito, H.O. (2004). Sources and Determinants of Agricultural Growth and Productivity in Kenya.

Panta, H.K. (2018). Supply chain of subsidized chemical fertilizers in Nepal. Journal of Agriculture and Animal Science, 35: 9-20.

Saboor, A., Hussain, M. and Madhia, M. (2009). Impact of Micro Credit in Alleviating Poverty: An Insight from Rural Rawalpindi , Pakistan. Pakistan Journal of Life and Social Sciences, 7(1), 90-97.

Satyal, V. R. (2010). Agriculture in Decline. Economic Journal of Development, 11(1): 144-157.
Shrestha, R.S. (2018, February 28). Nepal puts LDC graduation plan on hold. The Himalayan Times. Retrieved from https://thehimalayantimes.com/business/ nepal-puts-league-of-developing-countries-graduation-plan-hold/

Stewart, W.M., Dibb, D.W., Johnston, A.E. and Smyth, T.J. (2005). The contribution of commercial fertilizer nutrients to food production. Agronomy Journal, 97 (1): 1-6, https://doi.org/10.2134/agronj2005.0001

Teshome, A. and Lupi, A. (2018). Determinants of Agricultural Gross Domestic Product in Ethiopia. International Journal of Research Studies in Agricultural Science (IJRSAS), 4(2): 12-20, https://doi.org/http:// dx.doi.org/10.20431/2454-6224.0402002 www.arcjournals.org

Thapa, Y.B. (2011). Agricultural Growth: Lessons for Redesigning Principles Y. Nepalese Journal of Agricultural Economics, 1(1).

Timmer, C.P. (1988). The Agricultural Transformation. In H. Chenery and T.N. Srinivasan (Eds.), Handbook of Development Economics (Vol. I, p. 328). Elsevier Science Publishers B.V.

World Bank. (2019). World Bank data base. Retrieved from https://data.worldbank.org/ 